\title{
Ageing behaviour of unary hydroxides in trivalent metal salt solutions: Formation of layered double hydroxide (LDH)-like phases
}

\author{
MICHAEL RAJAMATHI* and P VISHNU KAMATH \\ Department of Chemistry, Central College, Bangalore University, Bangalore 560 001, India
}

MS received 13 June 2000; revised 16 August 2000

\begin{abstract}
The hydroxides of $\mathrm{Mg}, \mathrm{Ni}, \mathrm{Cu}$ and $\mathrm{Zn}$ transform into layered double hydroxide (LDH)-like phases on ageing in solutions of $\mathrm{Al}$ or $\mathrm{Cr}$ salts. This reaction is similar to acid leaching and proceeds by a dissolutionreprecipitation mechanism offering a simple method of LDH synthesis, with implications for the accepted theories of formation of LDH minerals in the earth's crust.
\end{abstract}

Keywords. Hydroxides; hydrotalcites; layered double hydroxides.

\section{Introduction}

Layered double hydroxides (LDHs) are modeled on the structure of $\operatorname{Mg}(\mathrm{OH})_{2}$ (mineral brucite) and consist of a stacking of positively charged layers of the composition $\left[\mathrm{M}_{1-x}^{\mathrm{II}} \mathrm{M}_{x}^{\prime \mathrm{III}}(\mathrm{OH})_{2}\right]^{x+}$ with anions $\left[\mathrm{A}^{n-}\right]$ intercalated in the interlayer region for charge neutrality (Carrado et al 1986). The LDHs are useful as anion exchange resins (Ookubo et al 1993), catalysts (Cavani et al 1991) and as electrodes for alkaline secondary batteries (Bauer et al 1990; Kamath et al 1994). While a variety of LDHs containing different combinations of divalent and trivalent cations have been synthesized, LDHs of some combinations form easily compared to others. $\mathrm{Mg}$ and $\mathrm{Ni}$ form LDHs easily with both $\mathrm{Al}$ and Fe by simple coprecipitation (Reichle 1986), but require prolonged hydrothermal treatment to form LDHs with $\mathrm{Cr}$ (Kooli et al 1995). On the other hand, $\mathrm{ZnO}$ readily reacts with a $\mathrm{Cr}\left(\mathrm{NO}_{3}\right)_{3}$ solution to yield the $\mathrm{Zn}-\mathrm{Cr} \mathrm{LDH}$ within minutes (Boehm et al 1977). $\mathrm{Mg}$ forms a $\mathrm{LDH}$ with $\mathrm{V}^{3+}$ on hydrothermal treatment (Rives et al 1993), whereas with Ga, simple precipitation yields a crystalline LDH (Lopez-Salinas et al 1997). The LDHs of $\mathrm{Cu}$ present a special problem, as cupric hydroxide is structurally different from other divalent hydroxides and $\mathrm{Cu}^{2+}$ being a Jahn-Teller ion is not well suited to occupy the octahedral sites in the LDH structure. Nevertheless, the LDH of $\mathrm{Cu}$ with $\mathrm{Al}$ has been obtained by the addition of strong alkali to a cuprammine sulphate solution containing $\mathrm{Al}^{3+}$ ions (Park et al 1990). After an extensive examination of all the parameters that influence the outcome of a precipitation reaction, Grosso et al (1992) synthesized a $\mathrm{Cu}-\mathrm{Cr} \mathrm{LDH}$, although not in a pure form. Other reports indicate single phase $\mathrm{Cu}-\mathrm{Cr}$

*Author for correspondence
LDH formation when precipitation is carried out at a constant low (5.5) pH (Depege et al 1994, 1996). Such a technique has also been employed for the synthesis of LDHs of Co with $\mathrm{Fe}$ at $\mathrm{pH} 6.5$ (Hansen et al 1994). While it is believed that coprecipitation at a constant low $\mathrm{pH}$ improves crystallinity, it has been observed that systems such as those of $\mathrm{Cd}$ with $\mathrm{Al}$ require a high $\mathrm{pH}$ (>13) for LDH formation (Vichi and Alves 1997). There appears to be no single preparative technique for $\mathrm{LDH}$ synthesis and minor variations in the experimental protocol are required for different systems.

In this paper, we report the formation of LDH-like phases on ageing the solid divalent hydroxides in an aqueous solution of a salt of a trivalent metal such as $\mathrm{Al}$ or Cr. Aqueous solutions of the salts of $\mathrm{Al}$ and $\mathrm{Cr}$ are highly acidic $(\mathrm{pH} 0-1)$ and these reactions are somewhat similar to acid leaching. Treatment with acidic solutions of salts instead of pure acids can, in principle, go beyond proton insertion and cation exchange for protons and lead to incorporation of different metal ions (such as $\mathrm{Al}$ or $\mathrm{Cr}$ ) into the solid. Moreover the observation of mineral LDH bands in brucite deposits outside the hydrothermal belt (Mondal and Baidya 1996) point to the possible formation of the LDH minerals by this process.

\section{Experimental}

Magnesium, nickel and cupric hydroxides, cupric oxide and zinc oxide were prepared by standard methods (Brauer 1965). 0.5 to $1 \mathrm{~g}$ of the unary hydroxide/oxide was made into a slurry in $5 \mathrm{ml}$ of distilled water and aged in $10 \mathrm{ml}$ of $0.5-1 \mathrm{~mol} \mathrm{dm}^{-3} \mathrm{Al}$ (or $\mathrm{Cr}$ ) salt (nitrate, sulphate or chloride) solutions at $65^{\circ} \mathrm{C}$ for 2 to 4 days. These salt solutions were highly acidic ( $\mathrm{pH} 0-1)$. The solid after ageing was filtered, washed free of anions and dried to constant weight at $100^{\circ} \mathrm{C}$. 
The products were characterized by X-ray diffractometry (JEOL JDX8P powder X-ray diffractometer, $\mathrm{CuK} \alpha$ radiation) and infrared spectroscopy (Nicolet Impact 400D FTIR spectrometer, $\mathrm{KBr}$ pellets, $4 \mathrm{~cm}^{-1}$ resolution).

\section{Results and discussion}

Table 1 shows the results of the ageing experiments. A majority of these experiments yielded single phase, although poorly ordered products. Figure 1 shows the powder X-ray diffractograms of the samples obtained by the ageing of copper(II) hydroxide in solutions of chromium nitrate and chloride. The prominent $d$-spacings are listed in table 2 . The patterns are completely different from that of the starting material and can be indexed on a hexagonal cell similar to the assignment made by other authors (Depege et al 1994, 1996). The LDHs of $\mathrm{Cu}$ could also be obtained by the ageing of $\mathrm{CuO}$. Figure 2 shows representative results of the ageing of $\mathrm{CuO}$ in a solution of aluminium nitrate. After $48 \mathrm{~h}$ of ageing, a highly ordered phase atypical of LDHs was obtained at the ambient temperature. This pattern corresponds to the

Table 1. A summary of the results of ageing unary hydroxides in solution of salts of trivalent metals.

\begin{tabular}{lccccc}
\hline & $\mathrm{AlCl}_{3}$ & $\mathrm{Al}\left(\mathrm{NO}_{3}\right)_{3}$ & $\mathrm{Al}_{2}\left(\mathrm{SO}_{4}\right)_{3}$ & $\mathrm{CrCl}_{3}$ & $\mathrm{Cr}\left(\mathrm{NO}_{3}\right)_{3}$ \\
\hline $\mathrm{Mg}(\mathrm{OH})_{2}$ & - & $\mathrm{HT}+\mathrm{Br}$ & $\mathrm{HT}$ & $\mathrm{AS}$ & $\mathrm{AS}$ \\
$\mathrm{Ni}(\mathrm{OH})_{2}$ & $\mathrm{HT}$ & $\mathrm{HT}$ & $\mathrm{HT}$ & $\mathrm{AS}$ & AS \\
$\mathrm{Cu}(\mathrm{OH})_{2}$ & - & $\mathrm{HT}$ & - & $\mathrm{HT}$ & $\mathrm{HT}$ \\
$\mathrm{CuO}$ & - & HT & - & $\mathrm{HT}$ & $\mathrm{HT}$ \\
$\mathrm{ZnO}$ & - & HT & - & HT & HT \\
\hline
\end{tabular}

HT: Hydrotalcite-like LDH; Br: brucite; AS: amorphous solid. hydroxysalt, $\mathrm{Cu}_{3}(\mathrm{OH})_{4}\left(\mathrm{NO}_{3}\right)_{2}$ (JCPDS PDF No. 45-0594). On further ageing, a new phase with a larger interlayer spacing corresponding to the $\mathrm{Cu}-\mathrm{Al} \mathrm{LDH}$ was observed.

Similar results were also obtained in the $\mathrm{Mg}$ and $\mathrm{Ni}$ systems. Figure 3 shows the powder X-ray diffractograms of the as-prepared nickel hydroxide and the samples obtained by ageing it in Al chloride, nitrate and sulphate solutions. Before ageing, the highest $d$-spacing observed for nickel hydroxide is at $4.6 \AA$ due to its (001) reflection. The diffraction patterns of the aged samples are completely different, with a new peak arising at around $8.0 \AA$ followed by another around $4.0 \AA$. The patterns of the aged samples are similar to those of the mineral takovite, as well as the $\mathrm{Ni}-\mathrm{Al} \mathrm{LDH}$ obtained by conventional methods (Bish and Brindley 1977). Similar results were obtained for the ageing of magnesium hydroxide which yielded hydrotalcite-like LDHs.

One of the characteristic features of the LDHs is the presence of anions intercalated between the layers. Infrared spectra have been used for the characterization of intercalated anions. In figure 4 the infrared spectrum of as-prepared magnesium hydroxide is compared with the spectrum of the sample obtained after ageing it in a solution of aluminium sulphate. $\mathrm{Mg}(\mathrm{OH})_{2}$ shows a sharp peak at $3650 \mathrm{~cm}^{-1}$ due to the $\mathrm{OH}$ stretch followed by a broad band characteristic of the brucite lattice in the low frequency region $\left(800-400 \mathrm{~cm}^{-1}\right)$. The aged sample on the other hand shows a broad band in the $3600-3300 \mathrm{~cm}^{-1}$ region due to $\mathrm{OH}$ groups hydrogen bonded to the intercalated water molecules. Further, strong vibrations are seen in the $1500-1000 \mathrm{~cm}^{-1}$ region due to the intercalated sulphate $\left(1124 \mathrm{~cm}^{-1}\right)$. Magnesium hydroxide aged in aluminium nitrate shows peaks at 1420, 1387 and $1350 \mathrm{~cm}^{-1}$ respectively, which are characteristic of nitrate

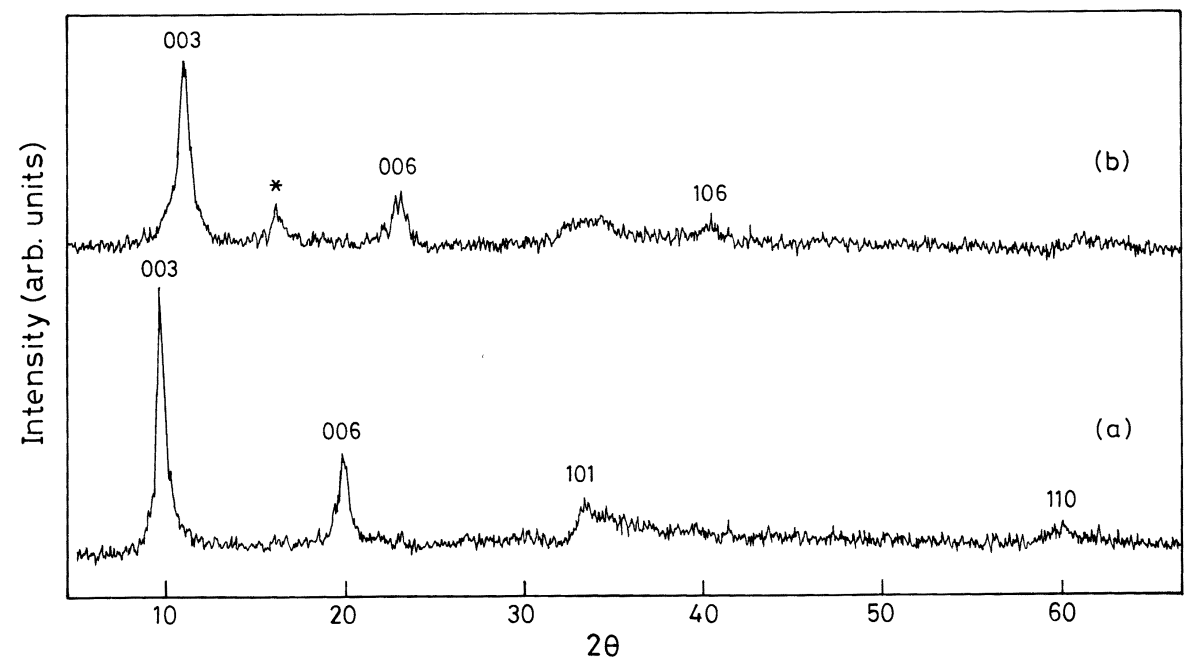

Figure 1. Powder X-ray diffraction pattern of copper (II) hydroxide aged in chromium (III) nitrate (a) and chloride (b) solutions. Feature marked by asterisk is due to impurities. 
ions intercalated in the $C_{2 \mathrm{v}}$ symmetry (Portemer et al 1992). The presence of intercalated anions, as seen from the infrared spectra is consistent with the increase in interlayer spacing observed by diffraction studies.

Chemical analyses of the LDH samples were done by a combination of gravimetric and complexometric techniques. Except for the $\mathrm{Cu}-\mathrm{Cr} \mathrm{LDH}$ which answered to the formula $\mathrm{Cu}_{2} \mathrm{Cr}_{1 \cdot 1}(\mathrm{OH})_{6 \cdot 3}\left(\mathrm{NO}_{3}\right)_{1 \cdot 1} \cdot 2 \mathrm{H}_{2} \mathrm{O}$, analyses of other LDHs did not lead to any consistent results. An excess of $\mathrm{Al}$ was found in most samples, probably due to the presence of X-ray amorphous $\mathrm{Al}(\mathrm{OH})_{3}$ and $\mathrm{AlO}(\mathrm{OH})$ phases.
Chemical coprecipitation of $\mathrm{Al}^{3+}\left(\right.$ or $\mathrm{Cr}^{3+}$ ) with divalent metals at high $\mathrm{pH}$ leads to the formation of carbonate intercalated LDHs. Special precautions have to be taken to obtain LDHs containing other anions such as chloride or nitrate (Wang et al 1992). In the present instance the LDHs are formed at a low $\mathrm{pH}$ which preclude carbonate incorporation and thereby LDHs containing nitrate, chloride and sulphate ions having their own characteristic interlayer spacings have been obtained.

Solid state transformations by acid leaching can take place topotactically or by a dissolution-reprecipitation mechanism. In the former case, the structure of the

Table 2. Powder X-ray diffraction data of layered double hydroxides obtained by the ageing of unary hydroxides in $\mathrm{Al}$ (or Cr) salt solutions.

\begin{tabular}{|c|c|c|c|c|c|c|c|c|c|}
\hline \multirow[b]{2}{*}{$h k l^{\mathrm{a}}$} & \multicolumn{9}{|c|}{$d / \AA$} \\
\hline & $\mathrm{Mg}-\mathrm{Al}^{\mathrm{b}} \mathrm{NO}_{3}^{-}$ & $\mathrm{Mg}-\mathrm{Al} \mathrm{SO}{ }_{4}^{2-}$ & $\mathrm{Ni}-\mathrm{Al} \mathrm{NO} \mathrm{N}_{3}^{-}$ & $\mathrm{Ni}-\mathrm{Al} \mathrm{SO} \mathrm{SO}_{4}^{2-}$ & $\mathrm{Ni}-\mathrm{Al} \mathrm{Cl}{ }^{-}$ & $\mathrm{Cu}-\mathrm{Al} \mathrm{NO}_{3}^{-}$ & $\mathrm{Cu}-\mathrm{Cr} \mathrm{NO}{ }_{3}^{-}$ & $\mathrm{Cu}-\mathrm{Cr} \mathrm{Cl}^{-}$ & $\mathrm{Zn}-\mathrm{Al} \mathrm{NO}_{3}^{-}$ \\
\hline 003 & $7 \cdot 83$ & $8 \cdot 76$ & $8 \cdot 76$ & $8 \cdot 59$ & $7 \cdot 66$ & $8 \cdot 60$ & 8.93 & $7 \cdot 79$ & $9 \cdot 12$ \\
\hline 006 & 3.93 & $4 \cdot 46^{\mathrm{c}}$ & $4 \cdot 38$ & $4 \cdot 31$ & $3 \cdot 85$ & $4 \cdot 33$ & $4 \cdot 48$ & 3.91 & 4.53 \\
\hline 103 & - & - & $2 \cdot 50$ & - & $2 \cdot 51$ & $2 \cdot 51$ & $2 \cdot 67$ & - & - \\
\hline 104 & - & - & $2 \cdot 43$ & - & - & - & $2 \cdot 45$ & - & - \\
\hline
\end{tabular}

${ }^{a}$ For phases showing only two lines, assignment has been done by comparison with the diffraction patterns of model compounds taken from the literature. For others a hexagonal cell has been used; ${ }^{b}$ weak lines due to starting materials persist even after prolonged ageing and are not listed here; ${ }^{c}$ broad.

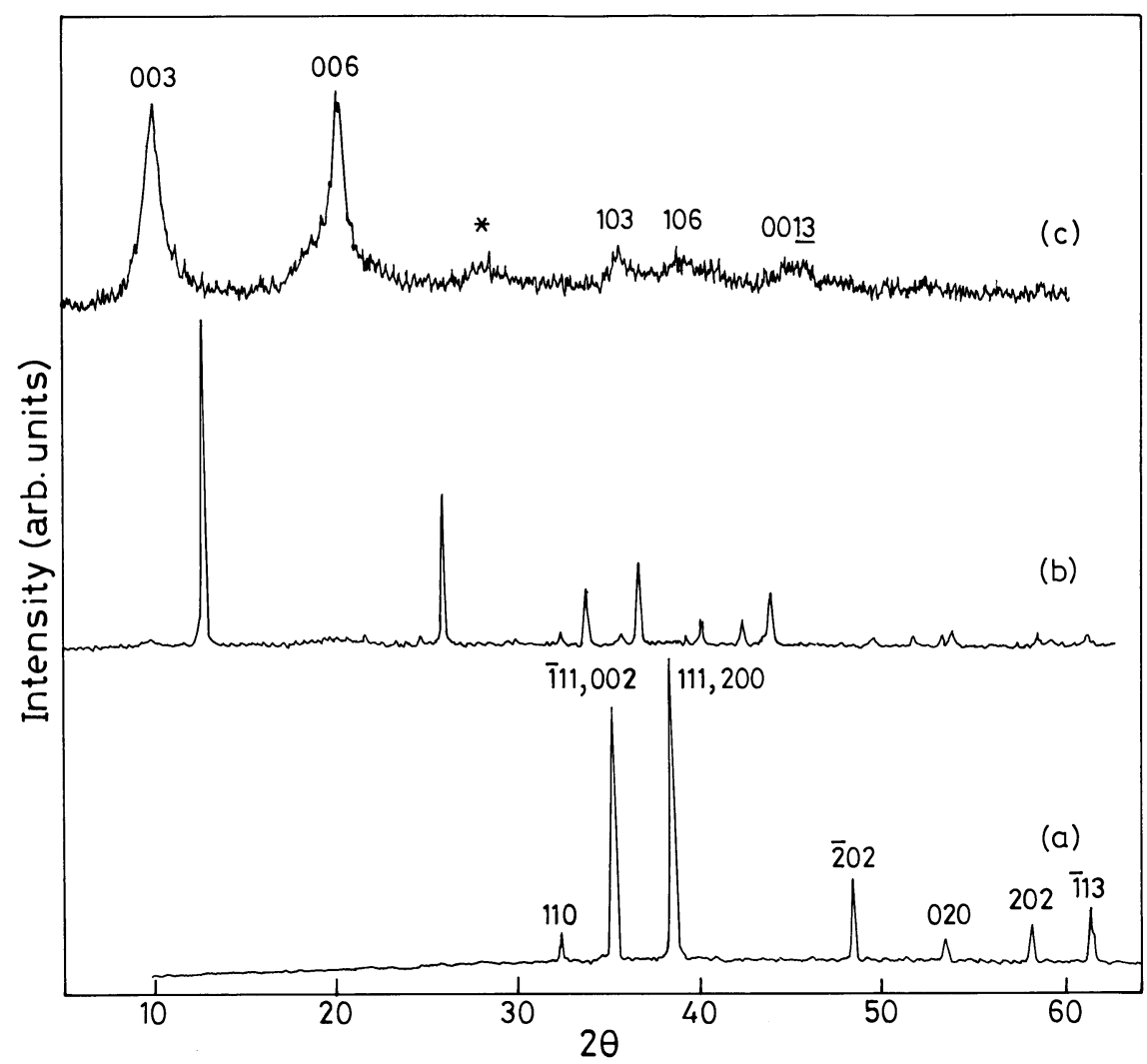

Figure 2. Powder X-ray diffractogram of $\mathrm{CuO}$ (a) compared with those of $\mathrm{CuO}$ aged in aluminium nitrate for 2 days (b) and 4 days (c). Feature marked by asterisk is due to impurities. 


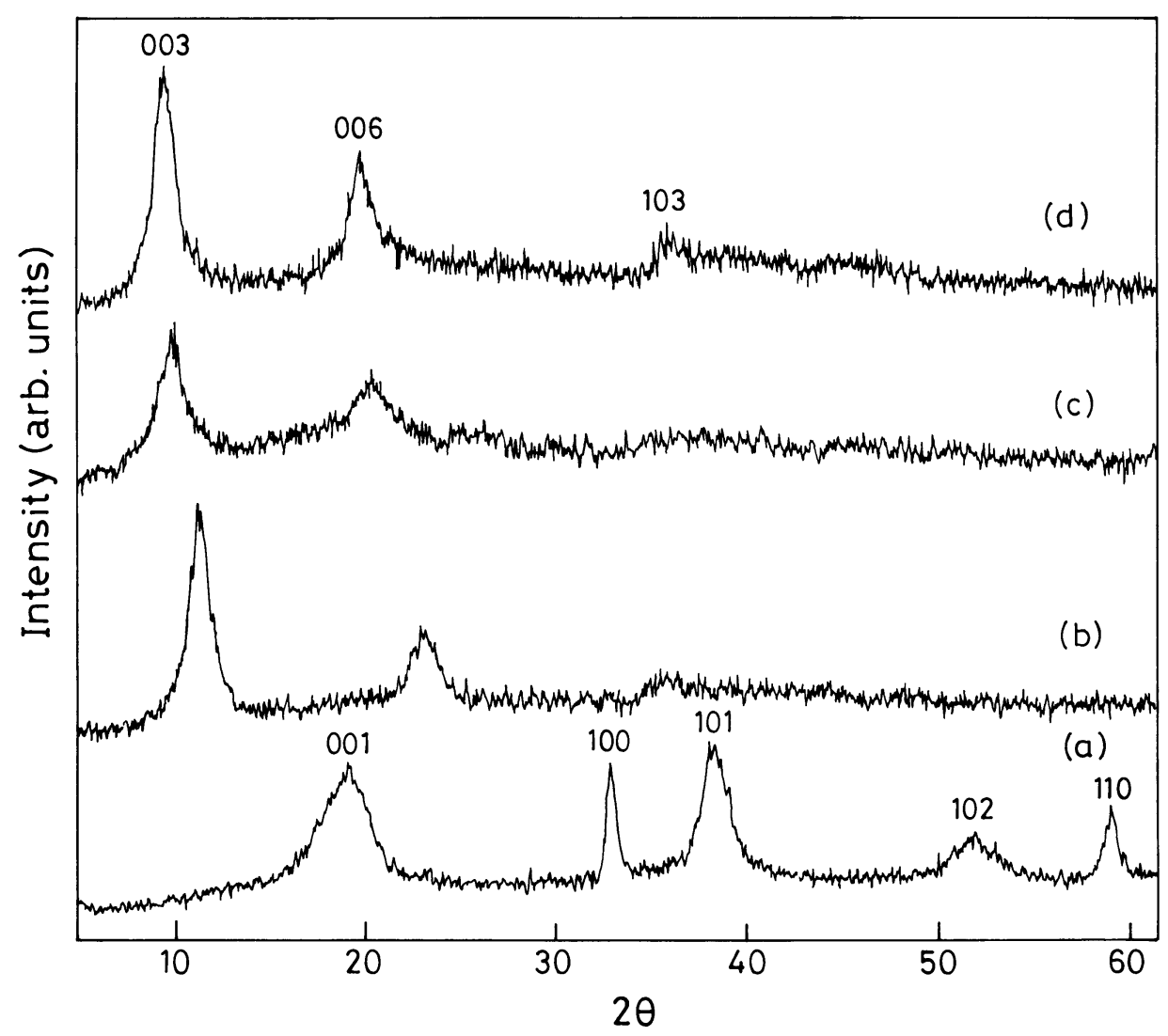

Figure 3. Powder X-ray diffraction pattern of nickel hydroxide (a) compared with those of nickel hydroxide aged in aluminium chloride (b), sulphate (c) and nitrate (d) solutions.

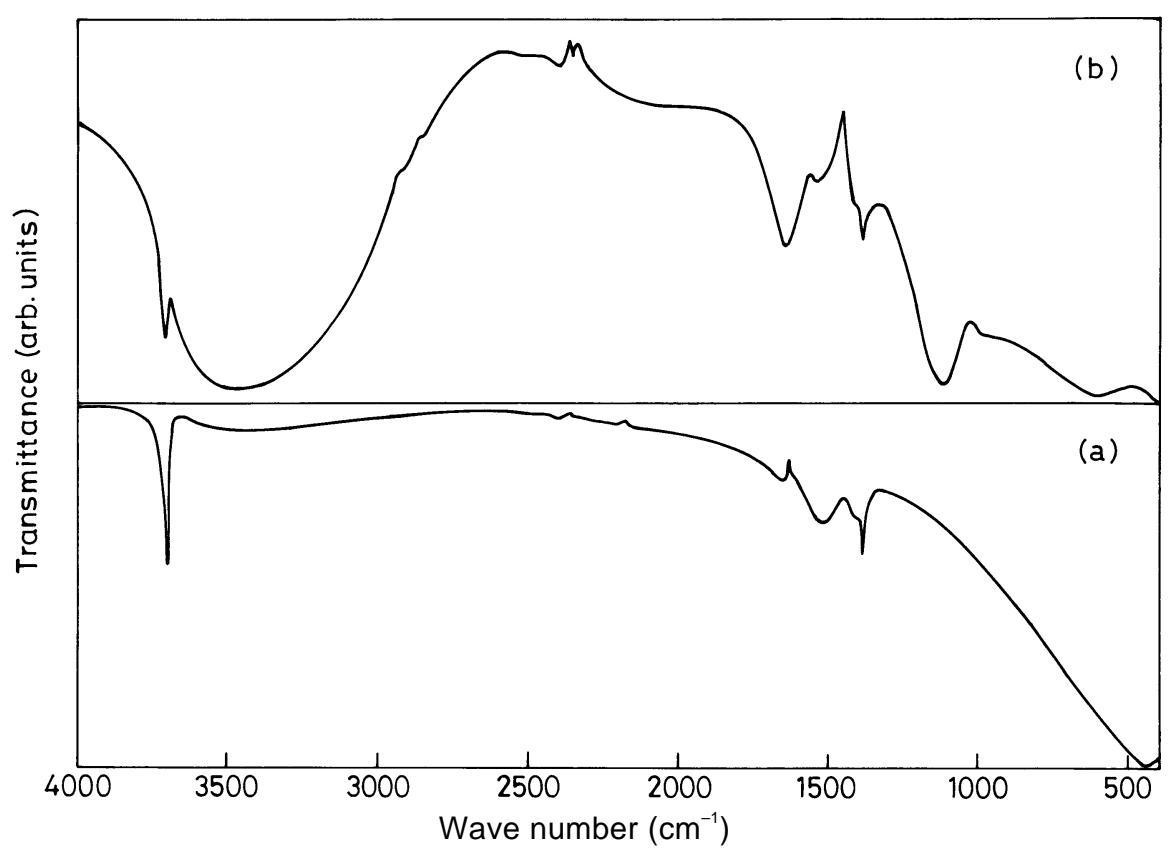

Figure 4. Infrared spectrum of magnesium hydroxide (a) compared with that of magnesium hydroxide aged in an aluminium sulphate solution (b). 
product phases are related to the structure of the reactant. In the present instance, both cupric hydroxide as well as $\mathrm{CuO}$ and $\mathrm{ZnO}$, all of which differ in their structures lead to isostructural LDH-like phases. Clearly the structure of the product formed is independent of the structure of the starting materials, indicating that this ageing reaction proceeds via the dissolution-reprecipitation mechanism.

These observations have important implications for the current understanding of the formation of mineral $\mathrm{LDH}$ deposits in the earth's crust. LDHs are mainly known to occur within the hydrothermal belt leading to the assumption that hydrothermal conditions are essential for the formation of LDH deposits. But the observation of mineral LDH bands in brucite deposits outside the hydrothermal belt is yet to be explained. It is well known that the $\mathrm{pH}$ of open and closed water bodies in nature can vary significantly in the range 2-9 depending upon the conditions. Ageing of brucite deposits in water bodies containing dissolved Al could easily explain these observations.

\section{Conclusions}

In this study we have demonstrated the formation of layered double hydroxide-like phases by the ageing of solid unary hydroxides in solutions of $\mathrm{Al}$ or $\mathrm{Cr}$ salts at temperatures close to the ambient $\left(<65^{\circ} \mathrm{C}\right)$.

\section{Acknowledgements}

The authors thank the Solid State and Structural Chemistry Unit, Indian Institute of Science for providing powder X-ray diffraction facilities and Prof. J Gopalakrishnan for useful discussions and some key ideas.
Financial support from the Department of Science and Technology, New Delhi, is acknowledged.

\section{References}

Bauer J, Buss D H, Harms H J and Glemser O 1990 J. Electrochem. Soc. 137173

Bish D L and Brindley G W 1977 Am. Min. 62458

Boehm H, Steinle J and Viewager C 1977 Angew. Chem. Int. Ed. Eng. 16265

Brauer G 1965 Handbook of preparative inorganic chemistry (New York: Academic Press)

Carrado K A, Kostapapas A and Suib S L 1986 Solid State Ionics 2677

Cavani F, Trifiro J and Vaccari A 1991 Catalysis Today 11173

Depege C, Forano C, deRoy A and Besse J P 1994 Mol. Cryst. Liq. Cryst. 244161

Depege C, Bigey L, Forano C, deRoy A and Besse J P 1996 J. Solid State Chem. 126314

Grosso R P, Suib S L, Weber R S and Schubert P F 1992 Chem. Mater. 4922

Hansen H C B, Koch C B and Taylor R M 1994 J. Solid State Chem. 11346

Kamath P V, Dixit M, Indira L, Shukla A K, Kumar V G and Munichandraiah N 1994 J. Electrochem. Soc. 1412956

Kooli F, Rives V and Ulibarri M A 1995 Inorg. Chem. 345122

Lopez-Salinas E, Torres-Garcia E and Garcia-Sanchez M 1997 J. Phys. Chem. Solids 58919

Mondal S K and Baidya T K 1996 Min. Mag. 60836

Ookubo A, Ooi K and Hayashi H 1993 Langmuir 91418

Park I Y, Kuroda K and Kato C 1990 Solid State Ionics 42197

Portemer F, Delahaye-Vidal A and Figlarz M 1992 J. Electrochem. Soc. 139671

Reichle W T 1986 Solid State Ionics 22135

Rives V, Lobojos F M, Ulibarri M A and Malet P 1993 Inorg. Chem. 325000

Vichi F M and Alves O L 1997 J. Mater. Chem. 71631

Wang J, Tian Y, Wang R and Clearfield A 1992 Chem. Mater. 41276 